\title{
The distribution and density of Tapanuli orangutans (Pongo tapanuliensis) at potential corridor locations between forest fragments in Batang Toru, North Sumatra, Indonesia
}

\author{
ARFAH NASUTION ${ }^{1, v}$, DYAH PERWITASARI-FARAJALLAH ${ }^{1,2, v v}$, S. SUCI UTAMI-ATMOKO ${ }^{3, v v \vee}$ \\ ${ }^{1}$ Department of Biology, Faculty Mathematics and Natural Sciences, Institut Pertanian Bogor. Jl. Meranti, IPB University Campus Dramaga, Bogor \\ 16680, West Java, Indonesia. Tel./fax.:+62-251-8625481, "email: arfah.nst@gmail.com \\ ${ }^{2}$ Primate Research Center, Institut Pertanian Bogor. J1. Lodaya II/5, Bogor 16151, West Java, Indonesia. Tel.:+62-251-8360712, Fax.:+62-251- \\ 8320417,vemail: witafar@gmail.com \\ ${ }^{3}$ Primate Research Center and Faculty of Biology, Universitas Nasional. Jl. Sawo Manila, Pejaten, Pasar Minggu, Jakarta Selatan 12520, Jakarta, \\ Indonesia. Tel.: +62-21-7806700, Fax.: +62-21-7802718, vwemail: suci_azwar@yahoo.co.id
}

Manuscript received: 5 August 2019. Revision accepted: 23 October 2020.

\begin{abstract}
Nasution A, Perwitasari-Farajallah D, Utami-Atmoko SS. 2020. The distribution and density of Tapanuli orangutans (Pongo tapanuliensis) at potential corridor locations between forest fragments in Batang Toru, North Sumatra, Indonesia. Biodiversitas 21: 5382-5388. The newly discovered Tapanuli orangutan (Pongo tapanuliensis) is in danger of being lost in a few decades due to their small population number in fragmented forest of Batang Toru. The major threats faced by this critically endangered ape, including: hunting, habitat loss, and fragmentation due to large infrastructure development and other developments in the key corridor area. The establishment of corridor and buffer zone is one such effort to maintain their population and bring them from the brink of extinction. Data on the population and distribution are needed to assess and provide baseline information for investigating the habitat condition of potential corridors and buffer zones. This study aimed to analyze population and distribution of Tapanui orangutan (Pongo tapanuliensis) in buffer zone and potential corridor of Batang Toru. Our study provides an initial dataset prior to the development of the hydrodam, which is important to understand the future post-development impact. The study was carried out in disturbed (Hutaimbaru and Bulu Mario) and undisturbed forest (Sitandiang and Hopong) of Batang Toru from June 2015 until February 2016. Orangutan nest, fig (Ficus spp.), and trees bearing fruit were recorded using a line transect method. This research showed that population and distribution of orangutan were influenced by forest conditions, threat level, and fruit availability. There were fewer nests per $\mathrm{km}^{2}$ in disturbed forest than in undisturbed forest, resulting in an orangutan density estimation to be $0.24 \mathrm{ind} / \mathrm{km}^{2}, 0.14 \mathrm{ind} / \mathrm{km}{ }^{2}$ (Hutaimbaru and Bulu Mario) and 0.74 ind $/ \mathrm{km}^{2}, 0.36$ ind $/ \mathrm{km}^{2}$ (Sitandiang and Hopong). Number of nest in transects was influenced by the availability of fig class I and class II, but not fruit tree. The APL forest of Sitandiang is key area to connect the three populations of Tapanuli orangutan: east Batang Toru, west Batang Toru, and Sibualbuali. Furthermore, orangutan's nests were encountered both in protected and non-protected forest, thus protection of such areas, especially areas including primary forest that harbor orangutan is essential for their long term survival. The conservation measures and action Tapanuli orangutan is alarming, thus we recommend all remaining habitat should be officially and strictly protected and collaboration work with multi-stakeholder is essential to establish the corridor as well as the strategic management plan of Tapanuli orangutan.
\end{abstract}

Keywords: APL forest, Bulu Mario, Hopong, Hutaimbaru, nest count, Sitandiang

\section{INTRODUCTION}

Orangutan is the only great ape found in Asia and restricted to the islands of Sumatra and Borneo. All the orangutan populations, including the newly discovered Tapanuli orangutan (Pongo tapanuliensis), are critically endangered (Ancrenaz et al. 2016; Singleton et al. 2017; Nowak et al. 2017) and continue to decline at a steady pace due to habitat loss, fragmentation, and hunting. Batang Toru is the last refuge for this southernmost orangutan population of Sumatra. The landscape has been fragmented overtime from 1989 to 2013 (Samsuri et al. 2014). This fragmentation split the population into several blocks: west block (581 individuals), east block (162 individuals), and Sibualbuali Nature Reserve (24 individuals) (Wich et al. 2019). This rediscovered population (Meijaard 1997) is genetically different compared with the North of Lake
Toba population (Nater et al. 2011) and described as a new species: Pongo tapanuliensis (Nater et al. 2017).

The Tapanuli orangutan long-term survival is in serious doubt (Sloan et al. 2018) due to road construction, illegal forest conversion, hunting, poaching, and killing (Wich et al. 2011). The conservation of Tapanuli orangutan is alarmingly important and needs serious attention because: (i) Tapanuli orangutan is the most threatened great ape in the world, even more threatened than the mountain gorilla (Hickey et al. 2018), (ii) Currently, a total of 767 individuals survive in the two wild populations (Wich et al. 2019), but neither of these populations will be viable in 500 years, with viability considered moderate to poor (west Batang Toru), and poor (East Batang Toru) (UtamiAtmoko et al. 2019). A combination of small population size and geographic isolation has led to inbreeding depression which was indicated in a recent study (Nater et 
al. 2017). One such effort to prevent this problem is the establishment of a buffer zone and corridor to connect the fragmented forest of Batang Toru, especially west and east Batang Toru. Yet population and distribution data of orangutan in the area is not available, further highlighting the importance of this study prior to the creation of a corridor establishment plan. We conducted an orangutan survey to identify the condition of orangutan population and its habitat at potential corridor locations as baseline data for further conservation measures. Our study provides an initial dataset prior to the development of a hydrodam, which is important as a pilot study as well as an assessment to determine the impact of such projects.

\section{MATERIALS AND METHODS}

\section{Study area}

The Tapanuli orangutan occurs in Batang Toru forest, with a total extent distribution area of $1,023 \mathrm{~km}^{2}$ (Wich et al. 2019) of $142.000 \mathrm{Ha}$ located within three districts of North, Central, and South Tapanuli, comprising of two blocks: East and West Batang Toru. The forest area is comprised of submontane and mountain forest with an elevation range of 50 to 1875 masl. (Perbatakusuma et al. 2007). The mean orangutan density of Batang Toru was $0.23 \mathrm{ind} / \mathrm{km}^{2}$ (Wich et al. 2016; Utami-Atmoko et al. 2019), which is the lowest compared to other populations in Sumatra, where densities range from 0.30-10.18 (Wich et al. 2004; Husson et al. 2009).

A satellite image showed that there is potential connection in Sitandiang, Bulu Mario, Hutaimbaru, and Hopong. The study was conducted at the border of Batang Toru forest: Sitandiang, Hutaimbaru, Hopong, and Bulu Mario (Figure 1). The forest is comprised of undisturbed (Sitandiang and Hopong) and disturbed forest (Hutaimbaru and Bulu Mario) with the allocation status is protected (Hutaimbaru) and non-forest use/area for conversion (Sitandiang, Hopong, and Bulu Mario). The forest of Hutaimbaru and Bulu Mario are split by roadways. The roadways of Bulu Mario split the west Batang Toru area, isolating the Dolok SibualBuali population. The area around the core of Sibualbuali NR which harbor small numbers of Tapanuli orangutan is mostly comprised of mosaic scrubland, agricultural field, and agriforest.
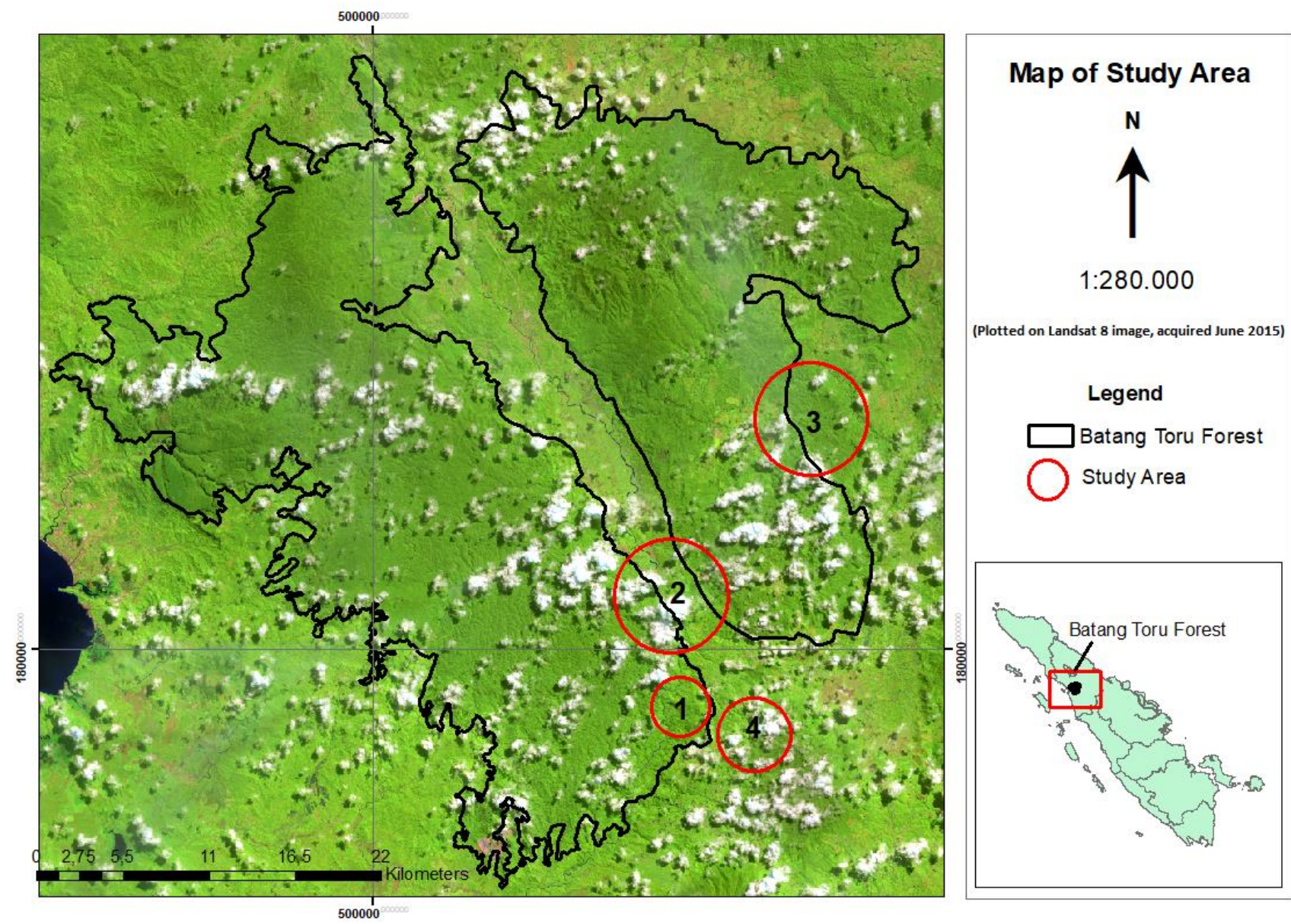

Figure 1. Map of survey area in Batang Toru, North Sumatra, Indonesia: 1. Sitandiang, 2. Hutaimbaru, 3. Hopong, 4. Bulu Mario (the base map is acquired from Landsat 8 image, June 2015) 


\section{Data collection}

Data of orangutan population was collected by nest count using line transect method, while data of fruiting tree abundance and fig density were collected by fruit trail and line transect method, both methods were conducted once (van Schaik et al. 1995; Wich et al. 2004). This survey was conducted by the first author with two experienced observers $(\sim 10$ years-experience in orangutan nest surveys). The transects were established randomly within a specific area that potentially connected populations using Landsat 8 images. Our transect direction was either south to north or east to west, adjusting for the placement of the potential corridor. Due to the rugged terrain in the field, some adjustment was necessary, as a consequence, the resulting transects did not look systematically randomized in several areas. Twelve transects in Sitandiang, Hopong, and Bulu Mario, while eighteen transects in Hutaimbaru were established, each equating 500 meters in length and 500 meters apart.

The location, number, and characteristics of detected nests were recorded. The characteristics recorded include: nest stage, nest type, nest height, nesting tree height, nesting tree diameter, nesting tree species, and perpendicular distance/PPD), fruit characteristics (species, fruit type, fruit condition, PPD), and fig characteristics (species, fig class, PPD). Perpendicular distance was measured using estimation of vertical distance between nest position to line transect. The nest stage was categorized into four categories following van Schaik et al. (1995), while the fig class was categorized into two classes following Atmoko and Rifqi (2012). Class I is strangling figs with living host-tree or fig tree with small canopy, while class II is strangling figs with dead host-tree or fig tree with full/big canopy.

\section{Data analysis}

The nest ppd data were analyzed using DISTANCE ${ }^{\mathrm{TM}}$ 7.3 (Buckland et al. 1993) to obtain nest density. Subsequently, the orangutan density (D) was calculated using the following formula: $D=N /(L \times 2 w \times p \times r \times t)$ in which: $\mathrm{D}=$ nest density $\left(\right.$ nest $\left./ \mathrm{km}^{2}\right), \mathrm{N}=$ number of nest observed along transect, $\mathrm{d}=$ orangutan density (ind $/ \mathrm{km}^{2}$ ), $\mathrm{L}=$ length of transect covered $(\mathrm{km}), \mathrm{p}=$ proportion of nest builders in the population (0.9/day, van Schaik et al. 1995), $\mathrm{r}=$ rate at which nests are produced (1.22/day, SOCP 2016), $\mathrm{t}=$ time during which a nest remains visible (501.5 days, Wich et al. 2016), $w=$ estimated width of the strip of habitat actually censused $(\mathrm{km})$, obtained from the effective strip width from the nest ppd data analysis on DISTANCE $^{\mathrm{TM}}$ 7.3. more perpendicular distances of nests were needed than those from one location onlt, thus to obtain an accurate estimate of $\mathrm{w}$, distributions of perpendicular distances of nests and figs were compared between habitat with the Wilcoxon test (nest: Wilcoxon W $=2961, \mathrm{P}<0.05$; fig: Wilcoxon $\mathrm{W}=1324.5, \mathrm{P}<0.05$ ). Both nests and figs showed that there is no significant difference of PPDs between habitat (disturbed and undisturbed), thus all perpendicular distances were combined in one ESW analysis using DISTANCE ${ }^{\mathrm{TM}} 7.3$ for nests and fig (both for class I and class II) (figure 2). Five recommended models were selected to determine the best fitted perpendicular data: uniform-cosine, half-normal-cosine/ hermite expansion, hazard rate-cosine/simple polynomial (Buckland et al. 1993). The best models were selected using Akaike's Information Criterion (AIC), the lowest AIC was used to estimate $\mathrm{w}$.

The nest density was analyzed using DISTANCE ${ }^{\mathrm{TM}} 5.0$ (Buckland et al. 1993), Consequently, the orangutan density (D) was calculated using the following formula: $d$

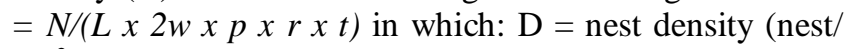
$\left.\mathrm{km}^{2}\right), \mathrm{N}=$ number of nest observed along transect, $\mathrm{d}=$ orangutan density (ind/ $\mathrm{km}^{2}$ ), $\mathrm{L}=$ length of transect covered $(\mathrm{km}), \mathrm{p}=$ proportion of nest builders in the population (0.9/day, van Schaik et al. 1995), $r=$ rate at which nests are produced (1.22/day, SOCP 2016), $\mathrm{t}=$ time during which a nest remains visible (501.5 days, Wich et al. 2016), $w=$ estimated width of the strip of habitat actually censused $(\mathrm{km})$, obtained from the effective strip width from the distance analysis. The estimated $w$ value for all locations was $15.42 \mathrm{~m}(\mathrm{n}=140)$.

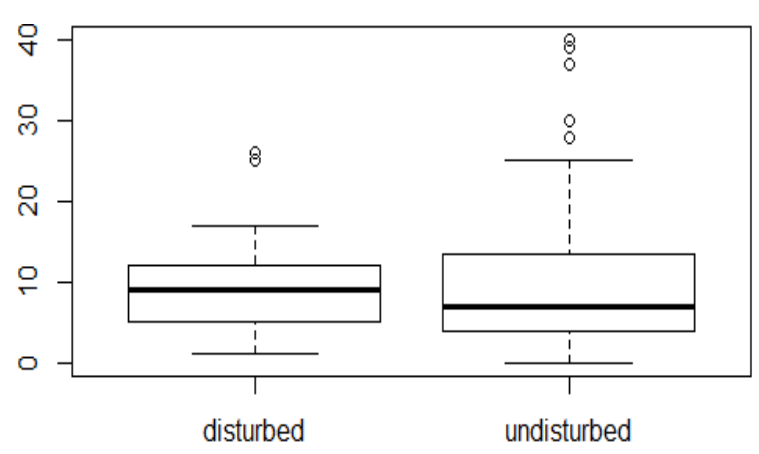

A

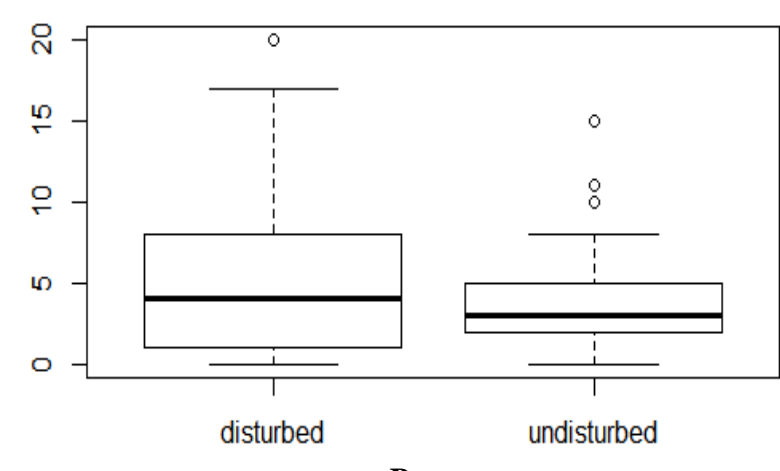

B

Figure 2. Plot of perpendicular distance of orangutan nest (A) and figs tree (B) in disturbed and undisturbed forest 
The fruiting trees availability was analyzed with the basic equation: $D=N / L$ with $\mathrm{D}=$ fruiting trees density, $\mathrm{N}$ $=$ number of fruiting trees, and $\mathrm{L}=$ area size. The correlation between fruiting trees and nest density per $\mathrm{km}$ was analyzed using non-parametric Spearman test. The fig density was calculated by basic equation: $D=N / 2 w L$, with $\mathrm{D}=$ ficus density, $\mathrm{N}=$ number of figs along transect, $\mathrm{w}=$ effective strip width, and $\mathrm{L}=$ transect length. PPD of figs from class I and class II were analyzed to estimate w value from the effective strip width obtained from the distance analysis. The estimated $w$ value for fig at all locations was $7.9 \mathrm{~m}(\mathrm{n}=106)$. A general linear modelling (RStudio Team 2016) was performed to investigate the relationship between number of figs and fruiting trees availability with number of nest in the transects.

\section{RESULTS AND DISCUSSION}

\section{Orangutan density}

A total of 140 nests were recorded at all locations (Table 1). Of these locations, 40.9 percent of nest was found in primary forest of Sitandiang with an elevation range 600-980 masl. The orangutan occurrence at this location was also confirmed from a long call, heard four times. The nest distribution follows a trend: more nests were found at higher elevation of each location. In Hutaimbaru, nests were predominantly found at elevation $700-800(41.2 \%)$, in Sitandiang (55.4\%) and Hopong $(64.9 \%)$ were at $800-900$ masl, while in Bulu Mario was at $>900$ masl $(50 \%)$.

The majority of nests class found in four locations are nest class $\mathrm{C}$ and $\mathrm{D}$, while the nest on class A was only found at Bulu Mario (Figure 3), this finding was confirmed by the locals that reported direct encounter in the area on observation week (Pers comm. 2016).

This study demonstrated that orangutans occupy areas of undisturbed high-quality forests at high altitudes. Our results are consistent with Wich et al. (2011), which found that the density of orangutan in Batang Toru is low in lower altitudes due to hunting history, leading them to disappear from the area. The majority of the lowland forest tends to be converted into agriculture and plantation where foods were not available for the orangutans. Furthermore, the reason why orangutan occurs more at higher elevations could be due to anthropogenic issues that typically occurred in lowland forests. Orangutan is very sensitive to forest encroachment and disturbance, thus forest conditions will affect orangutan density and distribution (van Schaik et al. 1995). Our study is consistent with Wich et al. (2011) which stated that orangutan density in Batang Toru is influenced by anthropogenic factors, such as logging and hunting. We also found that most of the forest edge was converted into agriculture and disturbed by logging activity, leading to the disconnection between forests, overlapped habitat, and conflict. The villagers reported that the orangutans are raiding their crops, ultimately impacting agricultural production, especially on petay (Parkia speciosa) and durian (Durio spp.) (Nasution et al 2018).

Our study provides an initial short dataset prior to the development of the hydrodam, which could be a database and pilot to understand the future post-development impact. Yet, we found a declining trend of orangutan population has occurred, particularly at Sitandiang and Hopong. Previous survey showed that density of orangutan in Sitandiang and Hopong was $0.82 \mathrm{ind} / \mathrm{km}^{2}$ (Sitaparasti 2007) and $0.7 \mathrm{ind} / \mathrm{km}^{2}$ (Fredriksson 2008, unpublished report), respectively. Yet, since the transects might not be the same, this assumption will also need to be re-assessed. Sitandiang provides primary forest with a low destruction stage (Sitaparasti 2007), thus it is not astonishing that more nests were found within this location. Interestingly, the nests were also found at the edge of primary forest which means that this area was also actively occupied by the orangutan.

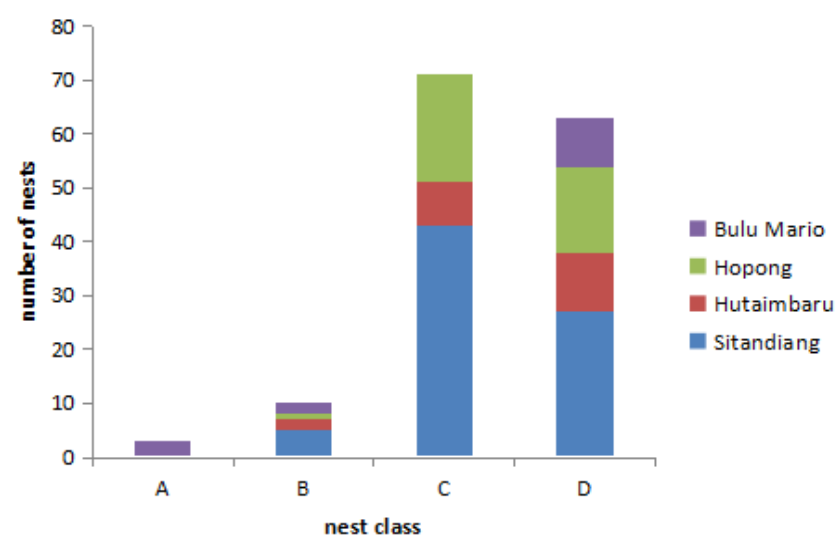

Figure 3. Nest class distribution at four locations

Table 1. Nests occurrence on survey areas

\begin{tabular}{lccccccc}
\hline \multicolumn{1}{c}{ Location } & $\begin{array}{c}\text { No. of } \\
\text { transects }\end{array}$ & ESW (m) & D & D LCL & D UCL & $\begin{array}{c}\text { D orangutan } \\
\text { (ind//km })^{\text {) }}\end{array}$ & Elevation \\
\hline Sitandiang* & 12 & 15.01 & 4,163 & 2.185 & 7.932 & 0.74 & $600-980 \mathrm{~m}$ asl. \\
Hutaimbaru** & 18 & 17.00 & 1.176 & 0.655 & 2.113 & 0.24 & $400-800 \mathrm{~m}$ asl. \\
Hopong* & 12 & 12.64 & 2,439 & 1.267 & 4.696 & 0.36 & $600-900 \mathrm{~m}$ asl. \\
Bulu Mario** & 12 & 26.00 & 0.449 & 0.201 & 1.003 & 0.14 & $700->1000 \mathrm{~m}$ asl.
\end{tabular}

Note: $*$ undisturbed forest, $* *$ disturbed forest 
In addition, the forest for other land uses (APL forest) of Sitandiang is key area to connect the three populations of Tapanuli orangutan: east Batang Toru, west Batang Toru, and Sibualbuali. Despite all of these interesting findings, this area was allocated for other land uses which tend to be converted (Gaveau et al. 2012). Furthermore, the majority of orangutan occurs in non-protected areas (Ancrenaz et al. 2016; Singleton et al. 2017; Nowak et al. 2017), including the APL forest, demonstrating that the protection of such areas, especially areas including primary forest that harbor orangutan is essential for their long term survival. Voigt et al. (2018) described the negative impact of natural resource extraction on orangutan populations with the most severe decline occurring when habitat was removed. All orangutan species are clearly protected in Indonesian law, thus the policies should be strictly implemented both to orangutan in the protected and nonprotected areas. Altering orangutan habitat will indirectly be killing orangutan. In addition, female orangutan will usually not move from their home range, even when their habitat has been destroyed (van Schaik 2004), which increases the risk of starvation and ultimately leads to death (Wich et al. 2019). Orangutan in disturbed areas tends to use the remaining forest intensively, leading to social tension between females (Ashbury et al. 2015).

\section{Nest distribution}

Nests were found both in protected and non-protected forests (APL and production forest). Nests found in Sitandiang, Bulu Mario and in-between showed that the area was moderately connected, which represents the corridor between West Batang Toru and Sibualbuali Reserve (Figure 2). More nests were found at Sitandiang and Hopong, an area of primary forest. Unfortunately, both locations are non-protected and allocated as forest for other land uses. At some locations, areas were claimed by locals by tree tagging (Sitandiang) and land clearing (Hopong).

Our result could not reflect the orangutan distribution trend in Batang Toru in general, as our transects were restricted to our area of interest based on potential connection between forests from Landsat 8 image acquired in June 2014. The field findings showed that a further spatial analysis to determine the corridor site and corridor strategy plan is essentials. We found that the potential corridor at Hutaimbaru (connecting West and East Batang Toru) is split by a provincial road, while the fringe of this road is a mosaic landscape, comprising of settlements, agriculture, agroforestry and scrubland. Sloan et al. (2018) suggested to close a segment of the 5-9 km existing roadway where the settlement and agriculture are sparse in the area. The nest distribution between Sitandiang and Bulu Mario showed that there is a potential corridor connecting the West Batang Toru and Sibualbuali. Wich et al. (2019) estimated six individual orangutans occur in the corridor between APL forest of Sitandiang and production forest around Sibualbuali. Furthermore, Wich and Geurts (2001, unpublished report) found that there is a connection between West Batang Toru and Sibualbuali as there is a mosaic degraded forest and gardens on either side of the dirt road of Bulu Mario. During our survey, the dirt road has become asphalt pavement $(\sim 3 \mathrm{~m})$ and used by public transportation as alternative route connecting Sibolga and Sipirok.

Sitandiang and Hopong comprised of primary and logged forest with low forest encroachment (Sitaparasti 2007; Susanto et al. 2008, unpublished report), these forest providing more food availability, including figs and fruit tree, while in Hutaimbaru and Bulu Mario, these were replaced by agriculture and plantation area. Other factors that led the land conversion at Bulu Mario and Hutaimbaru involve an increase in the human population around the location. Human population at the forest edge affected orangutan number significantly (Wich et al. 2016) due to the increase in land conversion. The APL forest of Sitandiang is important as the key area to connect the three populations of Tapanuli orangutan: east Batang Toru, west Batang Toru, and Sibualbuali, thus the official and strictly allocation, as well as conservation management of this forest, is essential.

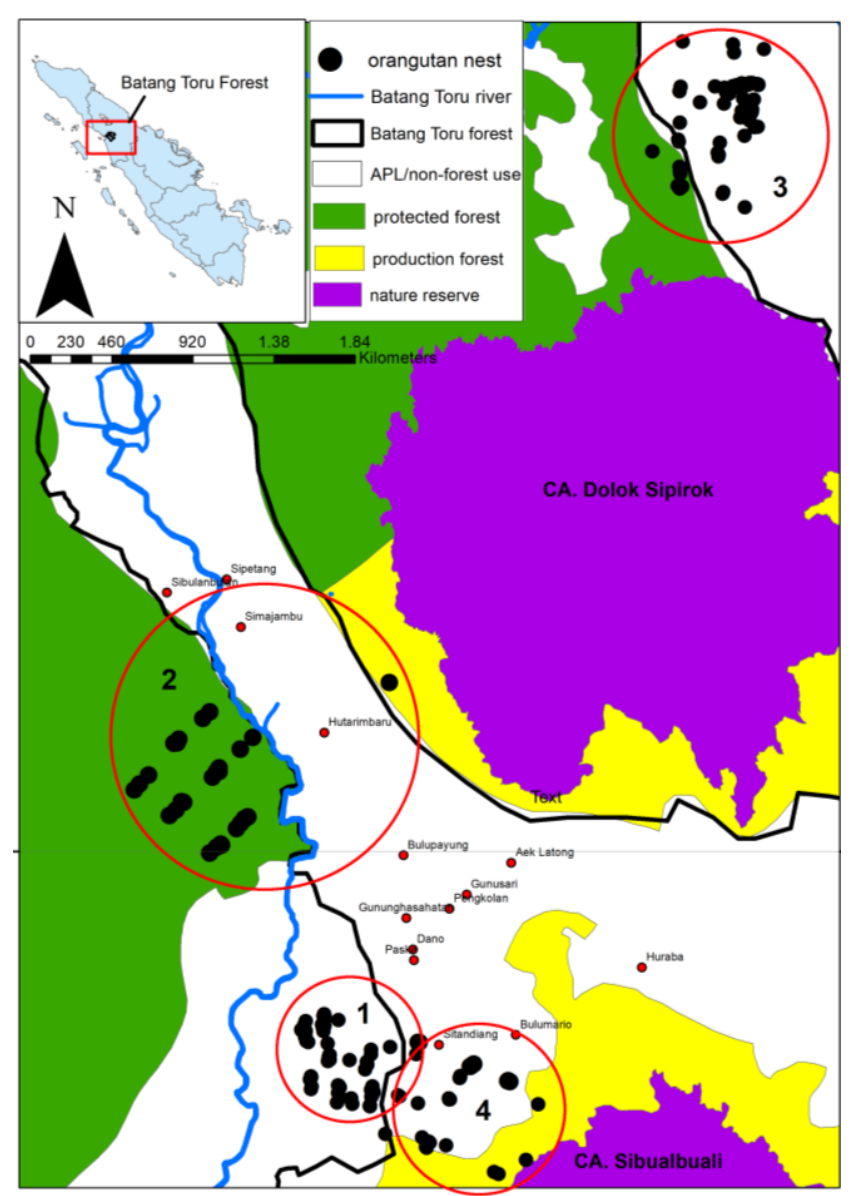

Figure 2. Map of nest distribution at study area 
Table 2. Ficus and fruiting trees density in study sites

\begin{tabular}{|c|c|c|c|}
\hline \multirow[b]{2}{*}{ Location } & \multicolumn{2}{|c|}{ Ficus density(ind/(km²) } & \multirow{2}{*}{$\begin{array}{c}\text { Fruiting trees } \\
\text { density } \\
\left.\text { (ind } / \mathbf{k m}^{2}\right)\end{array}$} \\
\hline & Class I & Class II & \\
\hline Sitandiang & 0.126 & 0.06 & 1.8 \\
\hline Hutaimbaru & 0.232 & 0.04 & 0 \\
\hline Hopong & 0.116 & 0 & 1.5 \\
\hline Bulu Mario & 0.379 & 0,001 & 0.2 \\
\hline
\end{tabular}

\section{Fruiting tree availability}

Fruiting trees and fig density varied between locations, yet we observed that the fruit trees were not abundant during the survey period, while the strangling fig was also not dense along the transect. Of all the locations, fruit season occurred primarily during the survey in Sitandiang, while more class I fig trees were found in Bulu Mario (Table 2).

More class I figs was recorded in disturbed forests (Bulu Mario and Hutaimbaru), while class II figs were recorded along transects at Sitandiang, Hutaimbaru, and Bulu Mario. Although the class I fig density in disturbed forest of Bulu Mario and Hutaimbaru was relatively high, the nest density was not. This might be due to the close distance with main road as well as overlapped with the local agriculture/agriforest. Number of nests in the transects was influenced by the availability of fig class I and class II (General Linear Model, AIC: 328.5, p < 0.05), but not with fruiting trees (General Linear Model, AIC: 328.5, $\mathrm{p}>0.05$ ). This might be due to small number of fruiting trees along the transects. In general, the distribution of orangutan nests in Batang Toru was clumped following the fruit tree availability that was also clumped. This phenomenon was also clearly observed at Hopong, where we found many old nests on an elevated path area with two and three nests in one tree. The fruit season in Batang Toru is not evenly-occurring, thus more nests were found clumped to fruiting trees (Sitaparasti 2007). In addition, due to hunting history in Batang Toru, the estimation of population based on ecology factors was not possible (Wich et al. 2004). Orangutan population in Batang Toru is dominantly influenced by anthropogenic factors, such as hunting and forest disturbance (Wich et al. 2012).

\section{Implication for conservation}

The Tapanuli orangutan is critically endangered, as its remaining habitat is small, fragmented, and poorly protected (Sloan et al. 2018). The remaining habitat is threatened by deforestation which occurs at steady pace at three blocks (Wich et al. 2019), thus all remaining habitat should be strictly protected (Fredriksson and Usher 2017). Orangutans with core areas in intermediate and highland areas depend seasonally on fruit production of lowland areas, and vice versa, thus conservation of large tracts of primary forest with a range of different altitudes is necessary to preserve the remaining orangutan population (Buij et al. 2002). Unfortunately, although a large part has been designated as protected forest, some key forest areas are still unprotected, leaving the rest open for logging and destructive development plans (Fredriksson 2017).
Population fragmentation due to the hydroelectric dam and road development is likely to increase the rate of decline of Tapanuli orangutan (Utami-Atmoko et al. 2019). Although the habitat destruction of Batang Toru was relatively low (Usher unpublished report, in: Wich et al. 2011), the population of orangutan is declining at steady pace. The future of Tapanuli orangutan population depends on the future rates of habitat loss, fragmentation, harvest, and how long these threats carry on before they are reduced or eliminated (Utami-Atmoko et al. 2019).

Tapanuli orangutan is struggling in fragmented forest of Batang Toru which only covers around $1000 \mathrm{~km}^{2}$ (Wich et al. 2016). This small area will lead to inbreeding depression, further complicating the situation and adding to the Tapanuli orangutan already fragile future, primarily caused by habitat destruction. The population of east Batang Toru and Sibualbuali are not viable for long-term survival, thus the blocks connectivity for genetic exchange is needed to establish a viable population. This conservation effort is challenging, taking time, and requiring further study. None of the population of Tapanuli orangutan are viable, the West Batang Toru population is estimated to decline slowly over time and has significant risk of extinction in 310 years, while East Batang Toru is decline to extinction in 124 years (Utami-Atmoko et al. 2019), thus conservation measures and action needed to save the habitat of this newly discovered great ape is alarming. The decline is entirely due to harvest/hunting, if it is stopped quickly, the population is able to recover as long as it is not fragmented (Utami-Atmoko et al. 2019). All remaining habitat should be maintained by the establishment of an official and strictly protected, including preventing these habitats from destruction and further fragmentation. Hence, we also support the IUCN SGA moratorium on the development in the core of Tapanuli orangutan range, including APL forest, until independent strategic environmental impact assessments are completed. This assessment includes: determining the implications of threats to orangutan in the APL forest as well as establishing the mitigation strategy and further spatial analysis to establish connection between forests. Last not least, a collaboration work with multi-stakeholder is essential to establish orangutan corridor and save the Tapanuli orangutan.

\section{ACKNOWLEDGEMENTS}

We wish to thank Yayasan Ekosistem Lestari (YEL)Sumatran Orangutan Conservation Program (SOCP) for facilitating the study. Thanks to our anonymous reviewer who helped us improved this manuscript and last but not least, PERHAPPI, Symposium and Congress of Indonesian Primate 2019 in Yogyakarta, Indonesia for sponsoring.

\section{REFERENCES}

Ancrenaz M, Gumal M, Marshall AJ, Meijaard E, Wich SA, Husson S. 2016. Pongo pygmaeus (errata version published in 2018). The 
IUCN Red List of Threatened Species 2016: e.T17975A123809220. DOI: 10.2305/IUCN.UK.2016-1.RLTS.T17975A17966347.en.

Ashbury AM, Posa MRC, Dunkel LP, Spillman B, Atmoko SSU, van Schaik CP, and van Noordwijk MA. 2015. Why do orangutans leave the trees? Terrestrial behavior among wild Bornean orangutans (Pongo pygmaeus wurmbii) at Tuanan, Central Kalimantan. American Journal of Primatology 77: 1216-1229

Buckland ST, Anderson DR, Burnham KP, Laake JL. 1993. Distance Sampling: Estimating Abundance of Biological Populations Chapman and Hall, London.

Buij R, Wich SA, Lubis AH, Sterck EHM. 2002. Seasonal movements in the Sumatran orangutan (Pongo pygmaeus abelii) and consequences for conservation. Biological Conservation 107: 83-87.

Fredriksson G, Usher G. 2017. Towards sustainable management of the Batang Toru ecosystem (translated from Edisi III dari "Menuju Pengelolaan Lestari Ekosistem Batang Toru") Yayasan Ekosistem Lestari, Medan.

Fredriksson G. 2017. Batang Toru, Tapanuli Sumatera. Yayasan Ekosistem Lestari, Medan. [Indonesian]

Gaveau DLA, Curran LM, Paoli GD, Carlson KM, Wells P, Besse-Rimba A, Ratnasari D, Leader-Williams N. 2012. Examining protected area effectiveness in Sumatra: importance regulations governing unprotected land. Conservation Letters 5(2): 142-148.

Hickey JR, Basabose A, Gilardi KV, Greer D, Nampindo S, Robbins MM Stoinski TS. 2018. Gorilla beringei ssp. beringei. The IUCN Red List of Threatened Species 2018: e.T39999A17989719. DOI: 10.2305/IUCN.UK.2018-2.RLTS.T39999A17989719.en.

Husson SJ, Wich SA, Marshall AJ, Dennis RD, Ancrenaz M, Brassey R, Gumal M, Hearn AJ, Meijaard E, Simorangkir T, Singleton I. 2009 Orangutan distribution, density, abundance, and impacts of disturbance. In: Wich SA, Utami-Atmoko SS, Setia TM, van Schaik CP (eds.). Orangutans: Geographic Variation in Behavioural Ecology and Conservation. Oxford Univ Press, New York.

Meijaard E. 1997. A Survey of Some Forested Areas in South and Central Tapanuli, North Sumatra; New Chances for Orangutan Conservation. The International MOF Tropenbos Kalimantan Project and the Golden Ark Foundation, Bogor.

Nasution A, Perwitasari-Farajallah D, Utami-Atmoko SS. 2018. Declining orangutans population in the unprotected forest of Batang Toru. Trop Life Sci Res 29 (2): 77-87.

Nater A, Nietlisbach P, Arora N, van Schaik CP, van Noordwijk MA, Willems EP, Singleton I, Wich SA, Goossens B, Warren KS et al. 2011. Sex-biased dispersal and volcanic activities shaped phylogeographic patterns of extant orangutans (genus: Pongo). Mol Biol Evol 28: 2275-2288.

Nater A. 2017. Mattle-Greminger MP, Nurcahyo A, Nowak MG, de Manuel M, Desai T, Groves C, Pybus M, Sonay TB, Roos C, Lameira AR, Wich SA, Askew J, Davila-Ross M, Fredriksson G, de Valles G, Casals F, Prado-Martinez J, Goossens B, Verschoor EJ, Warren KS, Singleton I, Narques DA, Pamungkas J, Perwitasari-Farajallah D, Rianti P, Tuuga A, Gut IG, Gut M, Orozco-terWengel P, van Schaik $\mathrm{CP}$, Bertranpetit J, Anisimova M, Scally A, Marques-Bonet T, Meijaard E, Krutzen M. 2017. Morphometric, behavioral, and genomic evidence for a new orangutan species. Curr Biol 27: 1-12.

Nowak MG, Rianti P, Wich SA, Meijaard E, Fredriksson G. 2017. Pongo tapanuliensis. The IUCN Red List of Threatened Species 2017: e.T120588639A120588662. DOI: 10.2305/IUCN.UK.2017-3.RLTS.T120588639A120588662.en.

Perbatakusuma EA, Supriatna J, Rondang SES, Wurjanto D, Sihombing L, Sitaparasti D. 2006. Laporan Teknik Mengarusutamakan Kebijakan Konservasi Biodiversitas dan Sistem Penyangga Kehidupan di Kawasan Hutan Alam Sungai Batang Toru Provinsi Sumatera Utara. Program Konservasi Orangutan Batang Toru. Departemen Kehutanan-Conservation International, Jakarta. [Indonesian]
Samsuri, Jaya INS, Kusmana C, Murtilaksono K. 2014. Analysis of tropical forest landscape fragmentation in Batang Toru watershed, North Sumatra. Jurnal Managemen Hutan Tropika 20 (2): 77-85.

Singleton I, Wich SA, Husson SJ, Stephens S, Utami-Atmoko SS, Leighton M, Rosen N, Taylor-Holzer K, Lacy R, Byers O. 2004. Orangutan population and habitat viability assessment: Final report IUCN/ SSC Conservation Breeding Specialist Group, Apple Valley, USA.

Singleton I, Wich SA, Nowak M, Usher G, Utami-Atmoko SS. 2017. Pongo abelii (errata version published in 2018). The IUCN Red List of Threatened Species 2017: e.T121097935A123797627. DOI: 10.2305/IUCN.UK.2017-3.RLTS.T121097935A115575085.en.

Singleton I, Wich SA, Nowak M, Usher G, Utami-Atmoko SS. 2017. Pongo abelii. The IUCN Red List of threatened species. 2017. e.T121097935A115575085. DOI: 10.2305/IUCN.UK.20161.RLTS.T17975A17966347.en

Sitaparasti D. 2007. Population and Distribution Sumatran Orangutan (Pongo abelii Lesson, 1827) in the Forest of Batang Toru Watershed North Sumatra. [Thesis]. Universitas Indonesia, Depok. [Indonesian]

Sloan S, Supriatna J, Campbell MJ, Alamgir M, Laurence WF. 2018. Newly discovered orangutan species require urgent habitat protection. Curr Biol 28: R1-R3.

Utami-Atmoko S, Traylor-Holzer K, Rifqi MA, Siregar PG, Achmad B, Priadjati A, Husson S, Wich S, Hadisiswoyo S, Saputra F, CampbellSmith G, Kuncoro P, Russon A, Voigt M, Santika T, Nowak M, Singleton I, Sapari I, Meididit A, Chandradewi DS, Ripoll Capilla B, Ermayanti Lees CM. (eds.). 2019. Orangutan population and habitat viability assessment: Final report. Ministry of Environment and Forestry of Indonesia, Jakarta and IUCN/SSC Conservation Planning Specialist Group, Apple Valley, MN.

van Schaik CP, Azwar, Priatna A. 1995. Population estimates and habitat preferences of orangutans based on line transects of nests. In: Nadler RD, Galdikas BMF, Sheeran LK, Rosen N (eds.). The Neglected Ape. Plenum Pr, New York.

van Schaik CP. 2004. Among orangutans: Red apes and the rise of human culture. Harvard University Press, Cambridge MA.

Voigt M, Wich SA, Ancrenaz M, Meijaard E, Abram N, Banes GL, Campbell-Smith G, d'Árcy LJ, Delgado RA, ERman A, Gaveau D, Goossens B, Heinickie S, Houghton M, Husson SJ, Leiman A, Sanchez KL, Makinuddin N, Marshall AJ, Meididit A, Miettinen J, Mundry R, Musnanda, Nardiyono, Nurcahyo A, Odom K, Panda A, Prasetyo D, Priadjati A, Purnomo, Rafiastanto A, Russon AE, Santika T, Sihite J, Spehar S, Struebig M, Sulbaran-Romero E, Tjiu A, Wells J, Wilson KA, Kuhl HS. 2018. Global demand for natural resources eliminated more than 100,000 Bornean Orangutans. Curr Biol 28: 19.e1-e5.

Wich SA, Buij R, van Schaik CP. 2004. Orangutan density showed positive correlation with strangling fig tree density. Primates 45: 177182.

Wich SA, Fredriksson G, Usher G, Kuhl HS, Nowak MG. 2019. The Tapanuli orangutan: Status, threats, and steps for improved conservation. Conserv Sci Pract 1 (6362): e33. DOI: 10.1111/csp2.33.

Wich SA, Fredriksson GM, Usher G, Peters HH, Priatna D, Basalamah F, Susanto W. 2011. Hunting of Sumatran orangutans and its importance in determining distribution and density. Biol Conserv 146: 163-169.

Wich SA, Singleton I, Nowak MG, Utami-Atmoko SS, Nisam G, Arif SM, Putra RH, Ardi R, Fredriksson G, Usher G, Gaveau DLA, Kuhl HS. 2016. Land cover changes predict steep declines for the Sumatran orangutan (Pongo abelii). Sci Adv 2: 1-8.

Wich SA, Usher G, Peters HH, Khakim MFR, Nowak MG, Fredriksson GM 2014 Preliminary data on the highland Sumatran orangutan (Pongo abelii) of Batang Toru. In: Grow NB, Gursky-Doyen S, Krzton A (eds.). High Altitude Primates, Development in Primatology: Progress and Perspective. Springer Science+Business Media, New York. 